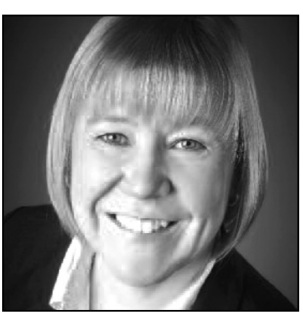

Annina H. Persson

Professor of Private Law Department of Law, Psychology and Social Studies, Örebro University

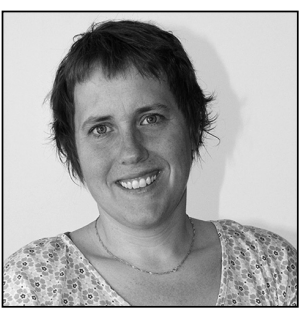

Ann-Sofie Henrikson

Doctoral Candidate of Private Law

Department of Law,

Umeå University

\title{
Regulation of Instant Loans and Other Credits in Swedish Law
}

\section{General overview}

Until the 1980 , the Swedish credit market was strictly regulated. In the wake of the deregulatory reform that took place in that decade, the range of consumer loans has since increased dramatically. Apart from ordinary mortgage loans and loans for more expensive goods, there are sales of all other sorts of consumer goods on credit, both in stores and via the Internet. Since 2006, there has also been a range of easy-access non-secured consumer loans (hereinafter 'instant loans') - in other words, short-term loans for relatively small sums that are to be repaid quickly. Characteristic of the instant loans is that they normally are also linked to a high APR and a certain fixed charge. In Swedish, the term 'SMS loan' is sometimes used, because the application for credit can in some cases be made via a text message (SMS).

The creditors are credit institutions - i.e., banks and credit-market companies but also other financial institutions. Credit institutions are regulated in their business primarily by the Banking and Financing Business Act ('Lagen (2004:297) om bank- och finansieringsrörelse'). Both banks and financing businesses require a licence for their operations where the Swedish Financial Supervisory Authority (FSA) is the regulator. A licence is also required for those financial institutions that provide loans to consumers. A new law has been introduced on certain undertakings that works with consumer credits, ('Lagen (2014:275) om viss verksamhet med konsumentkrediter'). ${ }^{{ }_{1}}$

In recent years, Swedish households have increased their debt levels significantly. ${ }^{{ }_{2}}$ Household debt has grown from $90 \%$ of disposable income in the mid-1990s to $171.7 \%$ in 2013 . Household debt is to a large extent due to the increase in mortgage loans. About $70 \%$ of households own their home, which is probably why $81 \%$ of household debt consists of mortgage loans. ${ }^{*}$ Many people experience problems with repaying their loans: 434,627 people had a debt that was registered with the Swedish Enforcement Agency in 2013, of whom $62 \%$ were men and $38 \%$ were women. The total amount of debt that the Enforcement Agency has to collect have increased, to about EUR 7.8 billion in 2013 from an annual level of about EUR 6.5-7 billion in

See FFFS 2014:8(Föreskrifter och allmänna råd om viss verksamhet med konsumentkrediter). (FSA, Regulations and guidelines on certain activities with consumer credits.)

2 See D. Finocchiaro et al. Hushållens skuldsättning, bostadspriserna och makroekonomin: en genomgång av litteraturen in Riksbanken ['Household debt, house price and macroeconomy: a review of the literature]. - Penning- och valutapolitik ['Monetary and exchange rate policy'] 2011/1, pp. 6-28.; Statens bostadskreditnämnd. Hushållens skuldsättning i spåren av finanskrisen -en internationell jämförelse ['Household debt in the wake of the financial crisis - an international comparison ]. Marknadsrapport (Market report), February 2011; M. Persson. Households indebtedness in Sweden and implications for financial stability - the use of household-level data. BIS Paper 46, May 2009.

3 Svenska bankföreningen (the Swedish Bankers' Association). Bolånemarknaden i Sverige ['The Mortgage Market in Sweden']. 2011, p. 6. 
each of the three preceding years. One explanation for the increase in debt is interest on existing debts. The largest group with debts handled by the Enforcement Agency consists of people who lack an income, but a second group with increasing debt levels is made up of those people with an annual income of over EUR 33,070. The debt level is increasing most in the $61+$ age group. The average debt across the various groups amounts to around EUR 4,400 per debtor. ${ }^{*}$

In 2012, 53,709 applications for an order for repayment of instant loans were filed with the Enforcement Agency. This represents an increase of $40 \%$ from the figure for the equivalent period in 2011. ${ }^{*}$ According to the Enforcement Agency, about 50,000 people in Sweden have a record of non-payment registered with the Enforcement Agency because of instant loans. In 2013, in total, 1,157,751 applications for an order to pay were made to the Enforcement Agency. According to the Enforcement Agency, one person usually has several records of non-payment registered against his or her name. The number of people behind the applications is not known, however, since the statistics are not maintained at the level of the individual. It is not uncommon for the first order to pay to have to do with a mobile-phone subscription, the second with e-trade, and the third with an instant loan. In all probability, the instant loans have been taken out to pay back other loans.

Bearing in mind the number of orders to pay and the fact that it has become easier to borrow money, one should not be surprised that the risk of individuals and families being affected by debt has increased. Worrying reports from both the Enforcement Agency ${ }^{*} 6$ and the FSA $^{*} 7$ indicate that $20 \%$ of all Swedish households have problems coping with unforeseen expenditure in the amount of at least EUR 2,200, and $10 \%$ of households (i.e., 350,00o) have problems making ends meet. The Enforcement Agency has estimated that about 400,000 people in Sweden are in debt. ${ }^{* 8}$ In 2008, there were 6,603 bankruptcies, 660 of which pertained to individual traders and 334 to natural persons. In 2012, there were 7,737 bankruptcies, with 878 associated with individual traders and 266 with natural persons. In 2008, 6,528 applications for debt restructuring were submitted, and 4,376 of the proceedings sought were initiated, while the equivalent figures for 2013 were 9,184 and 5,357, respectively. In conclusion, there has been an increase in the number of people who have problems paying, and this is probably connected to the debt crisis and the financial worries affecting large parts of the world.

\section{A legal and institutional overview}

Loans to consumers are covered by both the legislation on business operations, such as the Bank and Financing Business Act, and civil-law regulations, in the Consumer Credit Act (2010:1846). This act has incorporated the EC directive on credit agreements for consumers ${ }^{*}$. The point of departure of the Swedish Consumer Credit Act is, however, that the rules shall apply also to credit agreements that do not fall within the scope of the above-mentioned directive. Hence, the act addresses all types of credit that a trader may extend to a consumer. ${ }^{*}{ }^{10}$ The Consumer Credit Act is applicable to the loans a trader gives or offers a consumer-in other words, with respect to both credit agreements and the marketing of credit-as is made clear in the first paragraph of Section 1. The act also applies to loans that are given or offered to a consumer by someone other than a trader if the credit is provided by a trader acting as an intermediary for the creditor. The act also contains provisions for certain obligations for credit brokers, laid down in Section 1's second paragraph.

Not covered by the ambit of the law, however, are statutory loans that are submitted for state funding or loans issued by a pawnbroker in accordance with the Pawnbrokers' Act ('Pantbankslagen', 1995:1000), according to Section 3 of the Consumer Credit Act. Moreover, there is an exemption with regard to some of

4 See See the statistics from the Enforcement Agency at http://www.kronofogden.se/Statistik.html (most recently accessed on 30.1.2014) and C.-J. Lejland. Svenskarna sätter rekord i skulder ['The Swedes are setting records in debts']. - Dagens Industri, 6 October 2012, p. 6 (Today's Industry) (in Swedish).

5 See press release of the Enforcement Agency 28-08-2012.

6 See the Enforcement Agency report 'Alla vill göra rätt för sig' ['Everyone wants to do the right thing'], 2008; SOU 2008:82 p.70-75 (Vägen tillbaka för skuldsatta) (in Swedish).

7 Hushållens ekonomiska förmåga, Finansinspektionens rapport ['The financial capacity of households, FSA report'], number 27-06-2007 (in Swedish).

8 See Note 6.

9 Directive 2008/48/EC of the European Parliament and of the Council of 23 April 2008 on credit agreements for consumers and repealing Council Directive 87/102/EEC.

10 See Ds 2009:67, p. 58 (Ny konsumentkreditlag). 
the provisions for credit invoices-i.e., short-term credit that is given in conjunction with the sale of goods or services. The above-mentioned exemption also applies to certain credit-card loans, certain credit not linked to a purchase that has a short credit period and low charges, interest-free credit agreements, and credit agreements for free deferred payment of a current debt, according to the first to third paragraphs of Section 4 of the Consumer Credit Act. Mortgage agreements, which are not covered by the scope of the EC directive, fall within the scope of the act but, as is the case with credit that is given by investment companies or credit institutions for financing the purchase of financial instruments, only some of the provisions of the act apply; see Section 4 of the Consumer Credit Act (specifically, the fourth and fifth paragraphs). The rules that apply to consumer credit in general also apply to instant loans.

The regulatory authorities in the field of consumer credit-the FSA and the Swedish Consumer Agencyalso issue certain rules, among them the FSA's general guidelines regarding consumer credit and the Consumer Agency's general guidelines on consumer credit. ${ }^{* 11}$ These guidelines, or recommendations for how traders should act, are an expression of how the authorities believe the Consumer Credit act should be applied. They do not, however, require traders to act in the manner described or necessitate judicial review by a court. ${ }^{* 12}$

According to Section 49 of the Consumer Credit Act, it is the Consumer Agency that supervises the application of the Consumer Credit Act. This agency's supervisory role does not, however, cover either the Swedish National Bank (the Riksbank) or consumer credit provided by banks and credit-market companies, which are supervised by the FSA, or the Enforcement Agency's operations. The above-mentioned derogation entails most of the handling of consumer credit falling outside the remit of the supervisory operations of the Consumer Agency. With regard to operations supervised by the FSA, the derogation has been explained as being due to the fact that a trader who is already supervised by a certain authority should be supervised by the same authority where compliance with the Consumer Credit Act is involved. ${ }^{* 13}$ In Chapter 13 of the Bank and Financing Business Act, there are further, detailed provisions regarding the supervision carried out by the FSA vis-à-vis credit institutions and foreign financial institutions. In Chapter 8 of the same act, there are business provisions addressing the loan operations of a credit institution.

The supervision of compliance with the provisions of the Consumer Credit Act is thus shared between the Consumer Agency and the FSA. According to the travaux préparatoires of the act, the importance of the work of the two authorities being largely consistent is emphasised. ${ }^{* 14}$ The prerequisite is for these two authorities to consult each other with regard to supervisory matters. The question of whether not all lending establishments giving credit in accordance with the Consumer Credit Act should lie within the supervisory remit of the FSA in the same way as credit institutions has been discussed at length, ${ }^{*}{ }^{*}$ with such unification not yet in place.

The Consumer Agency in its supervisory capacity has the authority to order a trader to stop granting credit if that trader does not comply with the provision for credit assessments in Section 12 of the Consumer Credit Act, authority granted by Section 51 of that act. A decision regarding an injunction may be linked to a fine. If deeming it sufficient, the Consumer Agency may instead issue a warning. The warning can be combined with a penalty to the company that has not carried out adequate credit assessment of a consumer when granting credit. ${ }^{*} 6$ The penalty can be set at a minimum of 5000 SEK and a maximum of 10 million SEK, Section 52. According to the travaux préparatoires of the act, ordering a company to stop giving credit is a severe measure. Decisions as to whether such an injunction shall be issued must be made on a case-by-case basis. Flagrant or repeat infringements act in favour of an injunction. ${ }^{*} 17 \mathrm{In}$ its inspections of various pay-day loan companies in 2012-2013, the Consumer Agency found that the credit assessments

11 FFFS 2014:11(Finansinspektionens allmänna råd om krediter i konsumentförhållanden) and KOVFS 2011:1 (Konsumentverkets allmänna råd om konsumentkrediter).

12 Government Bill 1976/77:123, pp. 349-351(Regeringens proposition med förslag till konsumentkreditlag m.m.); A. Erikson, G. Lambertz. Konsumentkrediter. Kommentar till 1992 års konsumentkreditlag 1993, p. 331 and the following pages (Consumer credit. Commentary on the 1992 Consumer Credit Act).

13 See Government Bill 1976/77:123, p. 147; Lagutskottets betänkande (Legislation Committee report) 1977/78:5, p. 21; A. Erikson, G. Lambertz (see Note 12), p. 332.

14 See Government Bill 1991/92:83, p. 145 (Regeringens proposition om ny konsumentkreditlag).

15 See Government Bill 2009/10:242, p. 78 (Ny konsumentkreditlag).

16 See SFS 2014:83 and Government Bill 2013/14:34 (Sanktionsavgift vid bristande kreditprövningar.)

17 See Government Bill 2013/14:34 p. 17 c.f. Government Bill 2002/o3:139, p. 255 (Reformerade regler för bank- och finansieringsrörelse). 
carried out by many companies were inadequate. Between 2011 and 2013, 19 pay-day loan companies were given a warning for inadequate credit assessments. ${ }^{*} 18$

If a trader supervised by the FSA violates Section 12 of the Consumer Credit Act, the FSA has the right to take the measures stipulated in Chapter 15 of the Bank and Financing Business Act. The intervention shall be in the form of an injunction for certain measures to be taken within a certain amount of time or may consist of a ban on enforcing decisions or of an observation report. If the infringement is serious, the licence of the credit institution shall be revoked, whilst a warning shall be issued if one is sufficient. If the infringement is not serious or is excusable, the FSA may refrain from intervention. If a credit institution has been informed of a decision with regard to an observation report or warning, the FSA may decide that the institution in question shall pay sanctions. ${ }^{* 19}$

In conclusion, the Consumer Agency's sanctions associated with a trader violating Section 12 of the Consumer Credit Act are more limited than what applies to the FSA in relation to credit institutions. A further difference between the FSA and the Consumer Agency is that the idea is not for the Consumer Agency to inspect all traders under its supervision. Instead, the intention is for random inspections to be carried out. The Consumer Agency shall focus its resources primarily on targeted efforts where there is reason to believe that the Consumer Credit Act is not being complied with. It is, however, up to the agency to decide independently which measures shall be taken. ${ }^{* 20}$ As for the FSA, the work shall be geared mainly toward following the development of the business of individual companies on an ongoing basis so that the FSA can quickly make an assessment of a particular company and obtain a comprehensive picture of the risk exposure of that company. ${ }^{* 21}$

\section{Administrative measures}

\section{a. Licensing}

As described above, both banks and financing businesses are operations that require a licence and fall within the supervisory remit of the FSA. However, no licence is required for those so-called financial institutions that give credit to others than consumers without receiving repayable funds from the public. For these operations, it is the reporting duty in accordance with the Certain Financial Operations (Reporting Duty) Act that applies. (Lag (1996:1006) om anmälningsplikt avseende viss finansiell verksamhet). ${ }^{*} 2$ The scope of the latter act has been expanded several times ${ }^{* 23}$ and includes financial institutions-i.e., both natural and legal persons dealing with currency exchange or other financial activities. Here, 'other financial activities' refers to professional operations that consist primarily of providing one or several of the operations specified in paragraphs 2, 3, and 5-12 of Section 2 of the Bank and Financing Business Act's Chapter 7 (for example, giving or providing credit or credit with a lien in property or claims).

The categories of companies and private individuals registered as financial institutions with the FSA are highly varied. The list includes everything from major financial companies targeting qualified corporate customers to private individuals who work with currency exchange on a smaller scale. To complicate matters, there are operations that offer credit but still are not covered by the duty to report that is stipulated in the above-mentioned act. The financial activities have to be professional in nature if there is to be an obligation to report. Moreover, the company's main operations must consist of dealing with one or more of the activities listed in Section 1 of Chapter 7 of the Bank and Financing Business Act ((paragraphs 2, 3, and 5-12). Only companies that grant credit professionally and wherein the giving of credit is the main operation are subject to the duty to report. In order to reinforce the protection of consumers with respect to granting of credit and thereby reduce the problem of debt to the fullest extent possible, the legislator has

18 Press release from the Consumer Agency, http:// www. konsumentverket.se/ Lagar--regler/ Rattsarenden/ Varningar-enligtkonsumentkreditlagen/.Homepage of the Consumer agency, most recently accessed 6.8. 2014.

19 See Government Bill 2002/03:139, p. 381 and the following pages; Government Bill 2009/10:242, pp. 79, 121.

20 See A. Eriksson, G. Lambertz (see Note 12), p. 335.

21 See Government Bill 2002/03:139, pp. 372-373.

22 See amendments in the 1996 Act through SFS 2014:279 and 2014:561.

23 See for example Government Bill 1999/2000:145 (Penningtvätt och betalningsöverföring); Government Bill 2002/03:139, p. 598 (Reformerade regler för bank- och finansieringsrörelse) and note 22. 
introduced a new law on certain operations that involve consumer credit. ${ }^{* 4}$ As has been mentioned above, a licence from the FSA is required before one is allowed to pursue such activities.

\section{b. Marketing and advertising restrictions}

The Consumer Credit Act contains rules that, specifically for consumer credit, complement the general provisions on marketing set forth in the Marketing Act (2008:486). The EC directive on unfair businessto-consumer commercial practices has been incorporated into Swedish law with the latter act. ${ }^{*} 25$ Section 7 of the Consumer Credit Act, in its first paragraph, stipulates that a trader, when marketing credit agreements-of whatever sort-shall provide information about the APR for the credit. According to the second paragraph of Section 7, more detailed information shall be provided if the marketing includes a figure other than the APR. Examples include the interest rate and a charge or other cost. Despite the fact that the FSA supervises credit institutions for purposes of ensuring that they comply with the Consumer Credit Act with respect to credit assessments, it is the Consumer Agency that supervises the same institutions to ensure their compliance with Section 7 of the Consumer Credit Act with regard to the marketing of credit. The Consumer Agency thus conducts monitoring to ensure that all companies offering consumer credit comply with the Marketing Act's rules.

The Consumer Agency has noted that the marketing of pay-day loans has been aggressive. Therefore, the Consumer Ombudsman has in a few cases taken certain pay-day loan companies to the Swedish Market Court. In MD 2007:17, for example, the creditor was banned from marketing pay-day loans on the radio, television, and its own Web site and from portraying the credit as an easy and quick way to resolve financial problems. In MD 2010:30, the marketing used was regarded as not being compatible with good marketing practices, since the marketing had stressed the possibility of a quick credit solution as a decisive factor in relation to the conditions of other credit solutions.

\section{c. The system of debt counselling}

A person experiencing financial difficulties can seek advice from a budget and debt adviser, who can be found in any of the municipalities in Sweden. The availability of these services is required by law. The advisers may give advice on how to resolve a situation wherein an individual has incurred excessively large debts, by, for example, helping to draw up a household budget and assisting the debtor before and during a debtrestructuring procedure. One problem with the services of these advisers is that in some municipalities it may take as much time as 56 weeks before one can set up a meeting with a budget and debt counsellor. ${ }^{*} 6$ On the other hand, only three municipalities in Sweden fully lack access to a budget and debt adviser, ${ }^{*} 7$ and the advice is generally free of charge and is funded by the government. Demand for debt counselling has increased. In 2008, Sweden's municipal budget and debt counsellors had 12,505 clients, but in 2012, the figure had increased to $44,000 .^{*} 28$

Municipal consumer advisers too should be mentioned in this context. ${ }^{* 29}$ Their task is to provide general information, more details, and guidance to individual consumers on specific matters. ${ }^{*}{ }^{30}$ They can also act as a mediator in disputes between a specific consumer and a specific trader. Consumer guidance is available

24 See Ds 2013:26 (Viss kreditgivning till konsumenter), Government Bill 2013/14:107 (Om viss verksamhet med konsumentkrediter).

25 See Directive 2005/29/EC of the European Parliament and of the Council of 11 May concerning unfair business-to-consumer commercial practices in the internal market and amending Council Directive 84/450/EEC, Directives 97/7/EC and 2002/65/ EC of the European Parliament and of the Council and Regulation (EC) No 2006/2004 of the European Parliament and of the Council (the Unfair Commercial Practices Directive).

26 See SOU 2013:72, p. 133 (Ut ur skuldfällan).

27 Ibid.

28 See SOU 2013:78, p. 235 (Överskuldsättning i kreditsamhället?).

29 See also the Consumer Agency's report 2010:21. Kommunernas konsumentvägledning - bra men okänd ['The municipalities' consumer counselling - good but unknown]'. See the same report with respect to the four 'Consumer Bureaux' to which belongs for example Konsumenternas Bank- och Finansbyrå (the Consumers' Bank and Financial Bureau), which provide information and guidance to private persons in their respective markets.

30 See, for example, Government Bill 1985/86:121 (Regeringens proposition om inriktningen av konsumentpolitiken m.m.). 
in most municipalities, but about half of the population of Sweden know nothing of this, even though only seven per cent of the country's inhabitants live in municipalities without consumer-guidance officers of their own. In 2011, consumer-guidance officers dealt with 94,000 complaints. ${ }^{*}{ }^{31}$ The Swedish Consumer Agency estimates that these officers can mediate a settlement in about $95 \%$ of the disputes involved. ${ }^{*}{ }^{32}$

Several measures have been discussed for application, among them review of the structure of consumer support (for example, Web-based information provided by various players) and a national guidance service for individuals-a financial 'ER' designed to combat over-indebtedness. ${ }^{*} 33$

\section{d. Positive/negative credit registers}

It is fairly easy for a credit provider to make a reasonably reliable assessment of a potential credit recipient in order to establish whether that person risks becoming over-indebted. Firstly, the debtor must state the household's monthly income and expenditure in the credit application, along with its assets and liabilities. To facilitate the assessment, credit information is usually obtained from a specialist private company (one such company is Upplysningscentralen).

In the first paragraph of Section 2 of the Credit Information Act (1973:1173), credit information is defined as consisting of information, opinions, or advice submitted for guidance in the assessment of a person's financial creditworthiness or reliability. As for particulars related to private persons, the following information is usually included in the credit information: name, address, current residence, household members (i.e., national identification number(s) of any spouse and/or children under 18 living in the same residence), marital status, year of any immigration or emigration, and income figures from the annual income-tax assessment. If the debtor runs a business, particulars of any ownership of real estate and presentations of the balance of outstanding credit for which no security has been furnished or for which the only security consists of someone having provided a surety for the credit involved are included. Finally, particulars are given of any records of non-payment-i.e., failure to settle a debt in time.

The Credit Information Act applies to credit information related to both legal and natural persons, but the provisions differ in certain respects, depending on the character of the person involved. The main aim of the Credit Information Act is, however, to prevent one's personal integrity from being violated unduly because of the contents of the information conveyed or on account of false or misleading information being stored or disclosed. ${ }^{*} 34$ This is particularly important since no-one's details may be deleted from a creditinformation register. ${ }^{*} 35$

With certain exceptions, credit-information activities are permitted only after a licence has been obtained from the Swedish Data Inspection Board. One exception is that a licence is not required for a Swedish credit institution. Except in a few specific cases, credit-information activities are deemed to involve someone providing credit information against a fee or as part of business operations; see Section 1. There are about 15 companies that have been granted a licence from the Data Inspection Board to work with credit information. Most of the information, however, is submitted by a few major credit-information companies. They have created computer registers that contain information about all natural persons over the age of 15 in Sweden and all legal persons in the country. In the several amendments made to the Credit Information Act in recent years, the intention has been to reinforce privacy of individuals in credit-information operations. ${ }^{*} 36$ Since credit information is used for a credit assessment in determination of whether a consumer will be able to repay a loan, it is important that the pieces of credit information supplied be up to date, relevant, and correct. The credit-information companies retrieve information from many sources,

31 See the Consumer Agency's report 2012:4. Kommunernas konsumentvägledning - en lägesrapport 2012 ['The municipalities' consumer counselling system - a progress report, 2012'].

32 See A. Bakardjieva Engelbrekt. Från materiella regler till genomföranderegler: en ny fas i det europeiska rättssamarbetet på konsumentskyddsområdet ['From material rules to implementation rules: A new phase in the European judicial co-operation in the area of consumer protection']. - Europarättslig tidskrift ['European Law Magazine'] 2007, pp. 588-589.

33 See SOU 2013:72 and SOU 2013:78.

34 See Government Bill 2002/03:139, p. 209.

35 Ds 2008:34, p. 19 (Ett starkare skydd för den enskildes integritet vid kreditupplysning); cf. the Retention of Data Directive (Directive 2006/24/EC of the European Parliament and of the Council of 15 March 2006 on the retention of data generated or processed in connection with the provision of publicly available communications services or of public communications networks).

36 Ds 2008:34; Government Bill 2009/10:151. 
primarily public sources and registers-for example, the Swedish Tax Agency, the Enforcement Agency, and the Swedish Companies Registration Office registers. In principle, the information that can be obtained from the authorities is publicly available to everyone.

\section{e. Responsible lending obligations}

The Consumer Credit Act includes rules pertaining to 'responsible lending' in the form of the trader's obligation to provide pre-contract information, perform credit assessments, and adhere to good lending practices. These rules are in line with 'market law' and have been approved by the business sector. The aim of market rules is not primarily to protect the individual consumer; instead, it is to maintain competition and create a well-functioning market. The market rules set forth in the Consumer Credit Act, however, also are intended to protect the consumer and contribute to reinforcing the consumer's position. ${ }^{*}{ }^{37}$ The Consumer Credit Act does not, however, provide for any civil-law sanctions for infringements.

According to Section 6 of the Consumer Credit Act, the credit provider shall observe good lending practices in the relationship with the consumer. The credit provider shall safeguard the interests of the consumer to a reasonable extent and provide the consumer with the explanations he or she requires.

What constitutes good lending practices is determined through ethics rules that have been agreed upon by representatives from the sector and the supervisory authorities. Also, statements from the supervisory authorities can provide guidance as to the interpretation of the concept. ${ }^{*} 38$ Items 2.1.1 and 2.1.2 of the general guidelines issued by the Consumer Agency provide guidance with regard to the concept of good lending practices. The FSA in its guidelines refers only to Section 6 and 12 of the Consumer Credit Act. ${ }^{*} 9$ The guidelines are recommendations and are not mandatory. There are no contractual sanctions if the guidelines are not followed.

Under these terms, the trader shall provide the consumer with the explanations and information that he or she needs in order to be able to determine whether a credit agreement suits his or her needs and financial situation. The government bill that led to the Consumer Credit Act emphasises that the consumer may need explanations in order to be able to choose between types of credit or to be able to estimate the cost of the credit in question. The obligation to explain does not mean, however, that the trader is obliged to give advice to the consumer. The circumstances of an individual case may, on the other hand, be such that the trader, for reasons of good lending practices, should dissuade the consumer from concluding a credit agreement. It should be stated also that the obligation to explain applies, in principle, for the full duration of the agreement even if it is aimed primarily at providing the consumer with sufficient information to allow assessing whether the credit suits his or her needs and financial situation.

The obligation to explain shall be regarded as having been fulfilled when the trader has provided all the explanations that the consumer in question requires. The explanations must, therefore, be adjusted on the basis of the consumer's case-specific needs. That is why-according to the travaux préparatoires of the relevant act of law-it is not possible to state exactly which explanations shall be provided. The government bill, however, stresses that the information provided to the consumer by the trader about the main features of the proposed credit (see Sections 8-10) should often lead to explanations. Moreover, it emphasises that if a consumer so demands, the trader shall be prepared to explain in more detail the meaning of the information. It is often justifiable for the trader to explain to the consumer what will happen if payment is delayed even if the consumer has not requested that information. Furthermore, the trader should ensure in a suitable manner that the consumer has understood the explanations given in their important details. ${ }^{*} 0$

It is assumed that the concept of good lending practices includes the requirement that the lender shall provide the consumer with fair information about the credit. There is reason to impose greater demands for explanations to be given for certain types of credit-for example, credit that entails a particularly high

37 Government Bill 1992/92:83, p. 33 (Regeringens proposition om ny konsumentkreditlag); Government Bill 2002/o3:139, p. 587; Government Bill 2009/10:242, pp. 46. An important part of the consumer protection in the EC directive behind the Consumer Credit Act from 2010 consists of the requirement with regard to the trader's obligation to provide information. See 2010/11:CU5, p. 6, and see also Directive 2008/48/EC.

38 See Ds 1990:84 (Ny konsumentkreditlag), p. 45; Government Bill 2009/10:242, p. 90; Government Bill 1991/92:83, pp. 33-34.

39 See Chapter 2 of FFFS 2014:11 ( FFFS = Finansinspektionens författningssamling) and FSA decision memorandum 10-4628, 2011-10-05.

40 See KOVS 2011:1, 2.1.1 (Konsumentverkets allmänna råd om konsumentkrediter). 
risk of indebtedness and types of credit that are designed in such a way that it is difficult for the consumer to understand them. With respect to these types of credit, the credit provider shall base the information on the explanation needs of the consumer. This means that the consumer must be able to pose questions orally to a person who is an expert in the relevant area and receive an answer to those questions without delay.

However, if a consumer has previously concluded an agreement with regard to a certain credit product with the credit provider, the credit provider should normally presume that further explanations will not be necessary unless the consumer specifically asks a question.

\section{Contractual measures}

\section{a. Unconscionability doctrine}

A contract term that is unfair can be reconciled or disregarded, in the manner stipulated in the general clause of Section 36 of the Contracts Act (1915:218). The rule is designed in such a way that it can be applied in particular to benefit a weaker party, such as a consumer in relation to a trader, even if the rule can also be applied to equal parties to a contract. The idea is that Section 36 of the Contracts Act shall serve as a last resort for situations involving rights worthy of protection if and when the specific consumer-protection legislation cannot be applied. The paragraph was introduced in 1976 and is often used in legal cases as a last resort.

There are several reasons for a term in a contract to be regarded as unfair; these might involve the meaning of the term, the circumstances wherein the agreement was signed, events that took place later, or other circumstances. When a review is being made, the terms of the contract shall be considered in light of all the circumstances related to the contract and of the contract as a whole. If a court finds one term to be unfair, that term can be reconciled such that it becomes fair, or it can be disregarded entirely. After reconciliation, the rest of the contract normally remains as it is, although reconciliation or the disregarding of one term may also lead to a more extensively amended contract or to the contract becoming void. The fairness of a term shall be assessed on the basis of what is normal in similar circumstances in consideration of the legislation and trade practices. ${ }^{*}{ }^{41}$ However, Directive 93/13/EEC, on unfair terms in consumer contracts, also governs the assessment of Section 36 of the Contracts Act when consumer contracts are involved. This means that a standard term in a consumer contract is unfair under Section 36 if, contrary to the requirement of good faith, it causes a significant imbalance in the parties' rights and obligations under the contract to the detriment of the consumer. ${ }^{*} 42$ The directive proceeds from a more rigorous approach than does Section 36 , which means that unreasonable conditions shall be disregarded if the contract could exist without the condition. The courts should-instead of the unfair term-apply utilisation of dispositive law. This imposes a more stringent model for traders than the adjustment of the contract terms as provided for by Section 36 . In fact, the adjustment possibility under Section 36 has been further limited by the directive. In the assessment of whether a contract term is unfair, one may not consider circumstances that have come about since the conclusion of the contract, which could mean that the condition in question is considered reasonable. ${ }^{*} 43$

From the Supreme Court's case law to date-NJA (Nytt Juridiskt Arkiv, the Supreme Court periodical) 1996, p. 3 and NJA 1999, p. 304-we may conclude that the fact of a bank neglecting its duties of investigating the creditworthiness of the debtor can only exceptionally lead to the debtor or a guarantor being exempted from repaying the loan. ${ }^{*} 4$

\section{b. Responsible lending doctrine}

In conjunction with providing credit, the credit provider shall check to ensure that the consumer is in such a financial position as to be able to fulfil the terms of the credit contract, under Section 12 of the Consumer Credit Act. The rule is designed primarily to underscore the responsibility of the trader to ensure that

41 J. Ramberg, C. Ramberg. Allmän avtalsrätt, 8th edition. 2010, p. 175 (General contract law).

42 See Section 11 of the Law on contracts terms in consumer relationships ('lag (1994:1512) om avtalsvillkor i konsumentförhållanden').

43 See U. Bernitz. Standardavtalsrätt ['Law of standard contracts'], 8th edition. 2013, pp. 159-160.

44 See A.H. Persson. Protection of consumer non-professional surety guarantors in Sweden. - A. Colombi Ciacchi. Protection of Non- professional Sureties in Europe: Formal and Substantive Disparity. 2007, pp. 267-269. 
people do not borrow more money than they are able to repay, in order to combat indebtedness of consumers. ${ }^{*} 45$ The credit assessment shall be based on sufficient information about the consumer's financial situation, and credit shall be granted only if the consumer's financial position allows the ability to fulfil his or her contractual obligations. When the amount of credit is substantially increased, a new credit assessment shall be made, to enable an estimate of the current solvency of the borrower. The aim of a credit assessment is, accordingly, to appreciate the consumer's current and future solvency. The credit assessment should be based on written information or other reliable sources, such as a credit-reference check. A consumer's solvency should be assessed on the basis of his or her income, assets, expenditure, and debts, along with any credit documents. ${ }^{*} 46$

If the credit applicant lives in a household with other residents, the financial situation of the entire household should be taken into account to a suitable extent. The trader shall collect information about the consumer in this extent and, working from this information, make an appraisal of the consumer's solvency, then, on the basis of that assessment, determine whether the credit that has been applied for shall be granted or not. In this process, consideration should be given to reasonable living conditions; there is guidance to help the credit provider in the Consumer Agency's calculations of such costs. ${ }^{*} 47$ With regard to the condition that a credit check shall be based on sufficient information, the travaux préparatoires of the Consumer Credit Act asserts that the trader must collect enough information for ensuring that the assessment of the consumer's solvency with regard to the credit in question can be performed with as great a degree of certainty as possible. ${ }^{*} 48$

The trader is normally responsible for obtaining a holistic view of the financial situation of the consumer. For this, several sources of information might be required. The information normally includes the income of the consumer, along with details of other credit commitments. If the information indicates that solvency is uncertain on account of the income level, it might be important to look at capital. If a security will be given for the credit, information with regard to that security must be collected. The fact that a consumer provides a security for the credit does not normally have an impact on the credit assessment. Even if information about the value of the security indicates that it covers the credit amount and credit costs, the underlying rule is still that the customer must have sufficient financial resources to pay the charges, interest, and instalments at the rate that has been agreed on even without the security: the value of the security may decrease over time and might not be sufficient at the time of sale, and that could lead to a large amount of the credit remaining non-covered. ${ }^{*} 49$

Moreover, the travaux préparatoires of the act states that information indicating that there is no record of non-payment is not sufficient for granting of credit, no matter how small the amount of the credit is. Likewise, the fact that there is a record of non-payment should not on its own determine whether the credit applicant is deemed to lack the financial preconditions for fulfilling the associated obligations. A consumer may be solvent for the credit in question despite the existence of several records of non-payment. There is, however, nothing to prevent the credit provider from rejecting the credit application because of a record of non-payment.

When a trader collects information about a credit applicant, several sources of information may be required. Information can be retrieved from the consumer, from a credit-information company, from a database run by an authority (such as the Enforcement Agency), or from the credit provider's own database or other register. The sources of information that are used for any particular credit assessment, especially if they partially overlap, must be determined by the requirement that the assessment be based on sufficient information. ${ }^{*}{ }^{0}$ The consumer should normally be asked to say something about his or her financial situation, but information from the consumer is not sufficient in practice. The consumer's information should always be checked with the aid of an up-to-date credit-reference check. If the trader obtains information via a credit-reference check, the information obtained is, in combination with the information the

45 See Government Bill 2002/03:139, p. 587; cf. Ds 1990:84, p. 45.

46 See FFFS 2014:11, Chapter 2.

47 See KOVS 2011:1, 23 2; cf. Ds 1990:84, p. 53, regarding those on whom a credit check shall be carried out.

48 See Government Bill 2009/10:242, p. 100.

49 See Government Bill 2009/10:242, p. 100; cf. Government Bill 1991/92:83, pp. 106 and the following pages; Government Bill 2002/o3:139, pp. 252 and the following pages and p. 587.

50 See FFFS 2014:11 and decision memorandum FSA 10-4628. 
provider receives from the consumer, generally enough, though this depends on how complete and reliable the information from the credit-reference check is.

In several cases from the 1990s, the Supreme Court ruled that the consequences of deficiencies in a credit assessment can only in rare, exceptional cases entail the obligation to pay being reconciled in accordance with Section 36 of the Contracts Act. ${ }^{*}{ }^{1}$ The effectiveness of the sector-based sanction system has, because of these decisions, been questioned every so often. This is why a civil-sanction proposal has been up for discussion. ${ }^{*}{ }^{2}$ The travaux préparatoires of the current Consumer Credit Act states, however, that a sector-based sanction system is more suitable and more effective, and it is also compatible with the requirements of the underlying directive. ${ }^{*} 53$

\section{c. APRC / interest-rate restrictions}

The question of a cap on interest rates under Swedish legislation has been discussed several times. Proposals for the introduction of a cap on interest rates in the context of collection have been submitted by the Tax Agency, for example. ${ }^{*} 54$ The Consumer Agency has put forward proposals related to the possible introduction of a limit to the level of interest on overdue payments that can be agreed upon between a credit provider and a consumer. ${ }^{*} 55$ Commissioned by the Ministry of Finance to draw up a proposal, A. Eriksson favoured an interest rate not exceeding 15 percentage points above the percentage that corresponds to the reference interest applicable at any particular moment in time in accordance with Section 9 of the Interest Act (Räntelagen,1975:673). ${ }^{*} 56$ The proposals put forth have not led to an amendment of the law. The travaux préparatoires of the Consumer Credit Act states that proposals of an interest-cap have been criticised by several referral organisations. The Riksbank, for instance, described an interest-rate cap as a blunt instrument in comparison to provisions addressing unfair contract terms and usury. ${ }^{*} 57$

The issue of an interest-rate cap has also been discussed within the framework of the enquiry into amendment of the Debt Restructuring Act. ${ }^{*} 58$ The conclusion, however, was that directly limiting the possibilities for consumers to take out necessary or unnecessary credit on what can in objective terms be deemed 'rotten terms' should be kept to a minimum.

\section{d. Restrictions on interest (for late payment, in relation to claims for damages, etc.)}

Certain provisions related to interest can be found in both the Interest Act (1975:673) and the Consumer Credit Act. The Interest Act is to a large extent optional, unlike the Consumer Credit Act, which is mandatory. The point of departure of the Interest Act is that it is primarily the contract provisions pertaining to interest that apply. Section 1 of the Interest Act, in its second paragraph, stipulates that the act applies insofar as nothing else has been agreed upon, pledged, or specially prescribed. However, the amount of interest that a credit provider may charge for extending credit is not regulated by the Interest Act. On the other hand, Section 18 of the Consumer Credit Act includes a rule stipulating that the credit customer is obliged to pay a special charge for the credit, apart from or instead of interest, only if this has been agreed on and if said charge is related to costs incurred by the credit provider for the credit. According to the travaux préparatoires of the Consumer Credit Act, the aim of the provisions is to limit the possibility of the credit provider charging interest in the form of a fee. ${ }^{*} 99$ While there are rules about percentages in the Interest Act, the optional nature of the act leaves it up to the parties to decide the level of interest to be charged.

$51 \quad$ NJA 1992, p. 351; NJA 1993, p. 163; NJA 1994, p. 381; NJA 1996, p. 3; NJA 1996, p. 19; NJA 1999, p. 304; NJA 1999 , p. 408.

52 Ds 1990:84; Government Bill 1991/92:83, pp. 34-35; Government Bill 2009/10:242, pp. 56-57.

53 Government Bill 2009/10:242, pp. 56-57.

54 Skatteverkets redovisning den 27 december 2004 ['Tax Agency report, 27 december 2004']; see also SOU 2008:82, p. 293 (Vägen tillbaka för skuldsatta).

55 Konsumentverkets (Consumer Agency) report 2003:4, p. 31. (Överskuldsättning).

56 See A. Eriksson. PM 2005/1958, p. 50 (Konsumentskyddet inom det finansiella området).

57 See Government Bill 2009/10:242, p. 34.

58 See SOU 2008:82, pp. 214-215.

59 See Government Bill 1991/92:83, p. 53. See also the discussion above on cases MD 2008:3 and MD 2009:34, in the section on marketing. 
If nothing has been agreed upon explicitly, provisions are applied to the interest a consumer who has not paid a debt in time shall be charged from the deadline until the debt has been paid-i.e., interest on overdue payment. If the contract does not feature any terms pertaining to interest on overdue payments, interest shall be calculated for a year in line with a percentage that corresponds to eight percentage points above the reference interest rate applied at any given moment in accordance with Section 9 of the Interest Act. According to Section 9, the reference interest rate shall be determined every six months, through a special decision by the Riksbank. From 1 July until 31 December 2013, the reference interest rate was set at one per cent; accordingly, the interest on overdue payment amounted to nine per cent under Section 6 . However, the rule has never been applied. As the regulation is dispositive, the parties can probably decide upon, in addition to penalty interest, contractual interest for the time of default, but the legal situation is unclear. ${ }^{* 60}$ If a debtor has been prevented from paying in time by illness, unemployment, or a similar circumstance that he or she has not prevailed over and if an obligation to pay full interest in consequence of overdue payment is therefore regarded as unreasonable, the interest that otherwise would be charged may be reconciled; see Section 8 .

There are two provisions of Swedish law that, in practice, set a cap to the interest that may be charged for credit: there is a civil-law provision in Section 31 of the Contracts Act and a criminal-law provision in Chapter 9, Section 5 of the Penal Code. ${ }^{*} 61$ The aim of Section 31 of the Contracts Act is to prevent anyone from reaping obviously unreasonable financial benefits through misappropriation from someone else by abusing the other party's situation of disadvantage-in simple terms, taking advantage of a person's distress, innocence, thoughtlessness, or dependence on him or her in order to gain a benefit that is clearly disproportionate to the consideration afforded. Therefore, there must be a considerable difference in what is demanded of the two parties before the provision is applicable. Court proceedings should be prompted by the invalid action. The legal consequence for breaching Section 31 of the Contracts Act is that the contract is considered invalid. As in general procedural law, the burden of proof is on the party that alleges there to have been abuse.

Section 5 of Chapter 9 of the Penal Code stipulates in its first paragraph that a person who in connection with a contract or other legal transaction takes advantage of someone else's distress, innocence or thoughtlessness, or relationship of dependence on him or her in order to obtain a benefit that is clearly disproportionate to the consideration afforded or for which no consideration will be provided shall be sentenced for usury to a fine or, at most, two years' imprisonment. ${ }^{* 62}$ Also, a person shall be sentenced for usury who, in connection with the granting of credit in a business activity or other activity that is conducted habitually or otherwise on a large scale, obtains interest or another financial benefit that is manifestly disproportionate to the counter-obligation; see Chapter 9's Section 5, second paragraph. If the crime is gross, imprisonment for at least six months and up to four years shall be imposed.

Where the limit for usurious interest shall be set is not entirely clear. In NJA, the Supreme Court deemed a credit provider liable for usury in 1995 after that credit provider had offered and granted consumers loans with an APR of 125-137\%. The Supreme Court, however, declared that it is not possible to determine whether the price of credit is reasonable by merely looking at the APR. ${ }^{* 63}$ In order to conduct a fair assessment, one must take into account the amount of credit, the credit period, and how the credit costs are to be paid. An overall assessment must be made, therefore, of the interest and the terms in general. It has been repeatedly debated whether the APR on pay-day loans should not fall under the criminal-usury provision. The APR for one of the least expensive pay-day loans in the Swedish market was 1,746\% in May 2012, and the most expensive loan had an APR of 18,200\%. ${ }^{* 64}$ The Consumer Agency reported a pay-day loan company to the police for usury in 2012, but the company closed up shop and the criminal investigation therefore was closed.

60 M. Mellqvist, I. Persson. Fordran och skuld [Claims and liabilities], 9th edition. 2011, pp. 79-80.

61 See SFS 1962:700 (Svensk Författningssamling).

62 See N.O. Berggren et al. Brottsbalken. En kommentar ['The Penal Code - a comment'], 1 May 2012, accessed via the Zeteo information system, specifically the comment on Chapter 9, Section 5 of the Penal Code.

63 Cf. even NJA 1941, p. 44; 1955, p. 574; 1963, p. 195; 1964, p. 213.

64 Seehttp://www.svd.se/naringsliv/nyheter/sverige/astronomiska-rantor-for-sms-lan_7052339.svd, 3.9.2008 (most recently accessed on 6.8.2014) (Astronomical interest rates for payday loans). 
A licence from the Data Inspection Board is required for running a collection agency, under Section 2 of the Debt Recovery Act (1974:182). ${ }^{*} 65$ There are rules in the Debt Recovery Act on how a debt-recovery business may be run. The business shall apply good recovery practices and thereby not cause the debtor any unnecessary harm or inconvenience. Nor should the debtor be subjected to any undue pressure or any other undue recovery measures. Before legal action is taken, the debtor shall receive a claim in writing, and each claim shall state the name of the creditor and the basis for the claim. If the claim includes sub-items such as a capital receivable, interest, and charges for costs, these shall be presented individually. As for interest costs, the accrued interest, the percentage, the period, and the amount that together form the basis for the calculation shall be presented. The claim shall also indicate the deadline by which the claim must be paid at the latest.

The measures for which a debtor is obliged to pay the creditor and the amount to be paid are stated in the Act on Debt Recovery Costs (1981:739). The debtor has a duty to compensate for the cost of sending claim letters, amounting to EUR 20, in accordance with the requirements of the Act on Debt Recovery, and EUR 6.50 for a payment reminder, provided that the parties have agreed to this. If the debtor and creditor have jointly drawn up a payment plan for the remainder of the debt and this has been sent to the debtor, the creditor has the right to charge EUR 19 for it.

Only when the claim has not been paid before the deadline stated may legal action be taken. The debtor is obliged to reimburse the creditor for costs incurred during the recovery process if those measures were necessary.

\section{Insolvency law}

\section{a. Enforcement for debts}

Enforcement of payment of debts in Sweden is regulated by the Act on Order for Payment Procedure ('Lag (1990:746) om betalningsföreläggande och handräckning'). This method is very easy and inexpensive for the creditor to use in order to receive payment from the debtor. Provided that the due date for payment has passed and the debt is monetary in nature, the creditor may apply for a payment order against the debtor with the Swedish Enforcement Authority. ${ }^{*} 66$ Said authority then verifies the debt, which is done via the application. ${ }^{*} 67$

The application to the Swedish Enforcement Authority for an order for payment can result in any of three distinct outcomes, depending on the defendant's choice. Firstly, if the defendant pays the entire debt (or a part thereof), the Swedish Enforcement Authority must promptly be informed, with the application being withdrawn if the debtor pays the entire debt. Secondly, if the defendant contests the debt, the applicant may decide whether the application shall be passed on to a court for further processing or dismissed by the Swedish Enforcement Authority. Thirdly, if the defendant does not contact the Swedish Enforcement Authority, the latter shall issue a verdict, which states that the defendant is obliged to pay the debt associated with the claim. ${ }^{*} 68$

Only if the claim is deemed unjustified or unwarranted is the application immediately returned to the applicant. In that case, the applicant may request the Swedish Enforcement Authority to hand over the case to the court system, where the case shall then be processed. Otherwise, the Swedish Enforcement Authority dismisses the case. ${ }^{*} 69$ Debt recovery too is executed by the Swedish Enforcement Authority. An application for a payment order must state whether or not the Swedish Enforcement Authority should execute. Unless the applicant applies for later enforcement of the verdict, the order shall be executed immediately. ${ }^{*} 70$

65 The Debt Recovery Act is complemented with rules in the Debt Recovery Ordinance (1991:956) and the Data Inspection Board's regulations on licences (DIFSI 2011:1).

66 See Sections 1 and 2 of the Act on Order for Payment Procedure.

67 In the application, the claim and the grounds for it shall be stated so that the defendant understands what the claim is related to. When the application is submitted, the Swedish Enforcement Authority sends the defendant a letter providing for an order to pay on the basis of the claim. See Sections 10 and 25 of the Act on Order for Payment Procedure.

68 See Sections 33 and 42 of the Act on Order for Payment Procedure.

69 See Sections 23 and 33 of the Act on Order for Payment Procedure.

70 See Chapter 2, Section 1 of the Enforcement Code. 


\section{b. The debt-restructuring system}

When a bankruptcy is finalised in a Swedish court and a natural person is involved, he or she is not exempted from his or her debts after the proceeding. In such a situation, the most suitable solution is often to initiate debt-restructuring proceedings if the individual is insolvent and encumbered with debts that he or she probably will not be able to settle in the foreseeable future. Debt restructuring entails a debtor being wholly or partially exempted from the responsibility of paying off the debts in the course of the debt-restructuring process. The restructuring mechanism has several aims: Chief among them is for the restructuring to be rehabilitating. People with a high level of debt should have the possibility of solving their financial problems and thus given a second chance, an opportunity for a more tolerable life situation. This aim to rehabilitate, however, must be weighed against the creditors' valid interest in make their claims.

Debt-restructuring procedures are regulated by the Debt Restructuring Act (2006:548). ${ }^{*}{ }^{11}$ The Enforcement Agency alone processes restructuring cases, according to Section 2. That agency may grant restructuring even if one or several debtors are opposed to it. The Enforcement Agency also processes reviews of restructuring decisions, and the decisions of the Enforcement Agency can be appealed to the District Court.

It is the debtor who initiates the application for debt restructuring, according to Sections 10-11. Before applying for restructuring, the debtor may have tried to reach a voluntary agreement with the creditors. In order to reach such an agreement, the debtor may have received advice from a municipal debt and budget counsellor, as paragraph 2 of Section 2 points out. These counsellors shall also provide the debtor with support and advice for his or her application for debt restructuring and then, after the decision, provide the debtor with assistance for the full duration of the payment plan. The Consumer Agency is the co-ordinating central authority for municipal budget and debt counsellors, according to Section 2's third paragraph.

Debt restructuring may be granted to a natural person residing in Sweden if he or she is insolvent and so indebted that his or her ability to repay the debts in the foreseeable future cannot be presumed (this is referred to as the qualified insolvency condition) and if, in consideration of the debtor's personal and financial situation, it is appropriate to grant debt restructuring (this is the general appropriateness condition), See Section 4 of the Debt Restructuring Act. It should be noted that the two conditions stated in Section 4 are cumulative; in other words, both must be fulfilled for debt restructuring to be granted.

For completion of an assessment with regard to the appropriateness condition, the circumstances surrounding the origin of the debts, the efforts made by the debtor to settle the debts, and the way in which the debtor has participated in the course of the debt-restructuring decision process shall be taken into account.

In essence, the Debt Restructuring Act applies only to private individuals, but traders who are natural persons may, under certain circumstances, be granted debt restructuring as stipulated in Section 4 (fourth paragraph). ${ }^{*}{ }^{2}$ The debtor shall not have been prohibited from trading under the Trading Prohibition Act (1986:436), and, unless extenuating circumstances exist, the trader shall not previously have been granted debt restructuring; see Section $6 .{ }^{*} 33$ The two material conditions-the above-mentioned qualified insolvency condition and general appropriateness condition-are intentionally general in nature.

The implication of granted debt restructuring is that the debtor, for a set term-as a rule, five yearsshall live on limited financial resources, and any surplus that may arise shall be divided between/among the creditors. The division is normally determined by a payment plan that is drawn up when debt restructuring is granted. This division basically encompasses all financial debts that the debtor incurred before the date of the decision to start the restructuring process (under Section 7's first paragraph). Debt restructuring does not, however, include debts related to maintenance under family law or a debt for which the creditor has the right of pledge, the right of lien, or other preferential rights, according to Section 7's third paragraph.

It is the Enforcement Agency that is responsible for drawing up a debt-restructuring proposal, according to Sections 9 and 19. The debtor must, however, support the decision and actively participate in various ways in the processing of the case. The Enforcement Agency, as the body of first instance, decides whether to grant debt structuring or not, under Section 21. Before a decision is made, the proposal must be sent to all the creditors involved, but it should be pointed out in the letter sent to the creditors that failure to comment on the proposal made in the letter does not prevent a decision to grant debt restructuring; see Section 20.

71 See further changes in SFS 2011:472 (Svensk författningssamling).

72 See proposal for a new legislation, namely debt restructuring for entrepreneurs. See SOU 2014:44 (F-skuldsanering. En möjlighet till nystart för seriösa företagare) (F-Debt restructuring. An opportunity to a fresh start for serious entrepreneurs).

73 See NJA (Nytt Juridiskt Arkiv, the Supreme Court periodical) 2013, p. 689. 
The Enforcement Agency can, moreover, decide in favour of debt restructuring even regardless of one or more creditors actually being against the decision. A review shall be performed as soon as possible after the deadline given to the creditors in the letter requesting a response to the proposal. However, Section 29 does provide that the decision may be appealed to the District Court. It should be noted that a decision regarding debt restructuring entails a prohibition of enforcement measures, in accordance with Section 22.

To be able to decide whether a debtor shall be granted debt restructuring, the Enforcement Agency may obtain information from other authorities, under the terms of Section 14. If the Enforcement Agency decides to grant debt restructuring, this decision shall be announced, according to Section 21. The decision to grant debt restructuring entails, according to Section 23, the debtor being 'let off' from paying the debts associated with the debt-restructuring process to the extent to which these are reduced. With debt restructuring, the debtor is also, with certain exceptions, released from paying those debts that are not known about in the case at hand. A debt-restructuring decision may be executed before it has entered into legal force, according to Section 37; therefore, the payment plan is in effect from the date of the first decision.

There is sometimes reason to review a decision to grant debt restructuring; see Sections 24 and 26-28. If the debtor has employed certain unfair methods, the Enforcement Agency may revoke the decision to grant debt restructuring with respect to the claim of a creditor. If the debtor deviates from the payment plan and that deviation is severe, the Enforcement Agency may either revoke or amend the decision to grant debt restructuring. In particular, if the debtor deliberately refrains from adhering to the plan, the decision to grant restructuring shall be revoked, while amending the decision may be the measure applied in other cases. An amendment might, for instance, entail extending the end date of the payment plan.

Also, the Enforcement Agency may amend the decision to grant debt restructuring at the request of a debtor, under Section 25. The decision can be amended if the debtor's financial situation has improved or deteriorated substantially since the decision was made and this is not due to circumstances that could have been foreseen at the time of the decision or if extraordinary factors are involved. If the debtor has become financially better off, he or she should apply for an amendment in order to avoid a situation wherein the payment plan is extended because a creditor has found out about the change in circumstances and requested a review of the decision; see Section 24 and Section 26. When a decision on debt restructuring is amended, the payment plan may be extended by, at most, seven years, under Section 26 of the Debt Restructuring Act.

The Debt Restructuring Act has been found to be insufficient. The original act, which came into effect in 1994 has been subject for several inquiries and reviews. A government bill is being drawn up that deals with extending the possibility of being granted debt restructuring. ${ }^{*} 44$ Also an government inquiry with a strategy for combating indebtedness is recently written. ${ }^{*} 75$

\section{Legislation in development}

Currently, several legislative measures are being processed with the aim of improving the situation for people who have trouble making payments. The legislator has appointed several government commissions to map out the debt situation and to propose new measures for curbing over-indebtedness. Proposals have been made to implement 1) less complicated requirements for debt relief ${ }^{*} 76$; 2) amendment to and modernisation of the usury legislation; and 3) a 15-year final statute of limitations for claims that have not been fully paid, from the date of the payment decision and execution. ${ }^{*} 77$

In summary, a clear picture exists of the problems that exist in Swedish credit society. However, how to solve the problems is much debated among creditors, consumer organisations, and others, whereas the legislator has not been able to implement many solutions. Although the problems have been examined in several government investigations, reports, and analyses, the concrete legislative changes are few. Nor has there been any revolutionary new case law in favour of consumers from the Supreme Court. Therefore, it is impossible to say what measures would be most effective for solving the problems, since most options have not been tried yet. They remain only proposals.

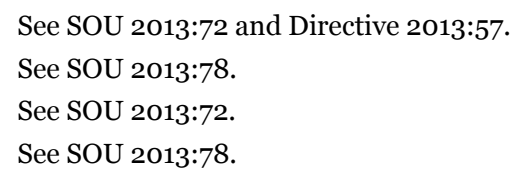

